\title{
PENGURANGAN LEAD TIME ANALISA KEMASAN PRIMER FLEXY BAG DENGAN METODE SINGLE MINUTE EXCHANGE OF DIES (SMED) DI INDUSTRI FARMASI $X$
}

\author{
Ayu Izzatin Haifa ${ }^{1}$, Nur Farida Permatasari ${ }^{2}$ \\ ${ }^{1}$ Farmasi / Politeknik META Industri / ayuizzatin@politeknikmeta.ac.id \\ ${ }^{2}$ Farmasi / Politeknik META Industri / nurfarida.permatasari@gmail.com
}

\begin{abstract}
Waste of time in the packaging analysis process can cause delays in the production process. This condition affects the speed in meeting consumer demand. Calculation of lead time analysis of packaging is important to calculate so that the release of packaging for production can be on time. In previous studies, an improvement that can be used to minimize waste is to reduce the internal set-up time to an external set-up using the single minute exchange of dies (SMED) method. This research was conducted experimentally by using observational data on testing parameters of packaging analysis from 1 batch number on 32 vat. Based on data from observations made on the primary packaging analysis of the flexy bag, there are 23 activities consisting of 18 internal activities and 5 activities that can be converted to external. The results of applying the SMED method in this study can reduce set-up time by $58.06 \%$ or 13.18 hours. So we get time efficiency by minimizing internal activities.
\end{abstract}

Keywords : lead time, waste, flexy bag, SMED

\begin{abstract}
ABSTRAK
Pemborosan waktu pada proses analisa kemasan dapat menyebabkan keterlambatan dalam proses produksi. Kondisi ini mempengaruhi kecepatan dalam memenuhi permintaan konsumen. Perhitungan lead time analisa kemasan merupakan hal penting untuk dihitung agar pelulusan kemasan untuk produksi bisa tepat waktu. Dalam penelitian sebelumnya perbaikan yang dapat digunakan untuk meminimalisir waste adalah dengan mereduksi waktu set-up internal menjadi set-up eksternal menggunakan metode single minute exchange of dies (SMED). Penelitian ini dilakukan secara eksperimental dengan menggunakan data hasil observasi terhadap paramater pengujian dalam analisa kemasan dari 1 nomor bats pada 32 vat. Berdasarkan data dari pengamatan yang telah dilakukan pada analisa kemasan primer flexy bag terdapat 23 aktivitas yang terdiri dari 18 aktivitas internal dan 5 aktivitas yang dapat dikonversikan ke eksternal. Hasil dari Penerapan metode SMED pada penelitian ini dapat penurunan waktu set-up sebasar $58,06 \%$ atau 13,18 jam. Sehingga didapatkan efisiensi waktu dengan meminimalkan aktivitas internal.
\end{abstract}

Kata Kunci : lead time, waste, flexy bag, SMED

\section{PENDAHULUAN}

Pesatnya perkembangan teknologi dan ilmu pengetahuan membuat persaingan antar perusahaan semakin ketat seiring dengan banyaknya perusahaan pesaing baru yang bermunculan dalam lingkup industri yang sama. Salah satu industri yang terus berkembang yaitu, industri farmasi. Hal utama yang harus dilakukan oleh suatu industri farmasi agar dapat bertahan serta mampu bersaing adalah dengan menjaga konsistensi mutu produk sesuai persyaratan dalam CPOB. Bagian yang berperan penting dalam pemenuhan persyaratan tersebut ialah pengawasan mutu atau quality control, diawali dengan menguji spesifikasi bahan awal, baik bahan baku obat maupun kemasan untuk memenuhi persyaratan yang ditetapkan. Kemasan digunakan sebagai 
pelindung sediaan obat terutama kemasan primer yang secara fisik bersinggungan langsung dengan produk (WHO, 2002).

Menurut Julianti (2018), kontrol kualitas kemasan sangat penting untuk selalu menghasilkan produk yang baik dan kompetitif sehingga potensi memenangkan persaingan akan semakin besar. Selain itu, diperlukan perbaikan kualitas secara terus menerus dan berkesinambungan agar dapat memberikan dampak signifikan dalam hal efisiensi waktu. Pemborosan waktu dapat mengakibatkan keterlambatan dengan lead time yang panjang dan berpengaruh terhadap penyesuaian industri farmasi dalam kecepatan memenuhi kebutuhan konsumen. Oleh karena itu, lead time analisa kemasan penting dihitung agar pelulusan kemasan untuk produksi bisa tepat waktu. Salah satu bentuk efisiensi tersebut yakni dengan penerapan sistem lean manufacturing yang berfokus pada penekanan pemborosan (waste).

Perbaikan yang dapat digunakan dalam meminimalisir waste adalah dengan mereduksi waktu set-up menggunakan metode Single Minute Exchange of Dies (SMED). Menurut Shingo (1985), tujuan utama dalam menerapkan metodologi SMED adalah untuk mempelajari kondisi lantai produksi secara detail melalui analisis produksi, wawancara dengan pekerja dan merekam video operasi set-up. Sivakumar et al. (2015), menerapkan SMED pada carriage building press, hasilnya mampu mengurangi waktu changeover sebesar 44,16 persen dari 98 menit menjadi 60 menit. Hal tersebut membuktikan metode SMED dapat menurunkan waktu set-up.

Berdasarkan penjelasan di atas dalam pelaksanaan lean ini, dilakukan salah satu upaya yang dapat memperbaiki sistem dalam mempersingkat waktu analisa, sehingga didapatkan efisiensi waktu. Perbaikan waktu set-up dilakukan untuk mereduksi proses analisa yang dipararelkan. Pengurangan waktu set-up dapat dilakukan dengan menggunakan metode SMED yang bertujuan untuk perbaikan setiap dasar operasi set-up internal dan eksternal.

Penelitian tugas akhir ini bertujuan untuk mengetahui hasil perhitungan lead time analisa kemasan primer flexy bag setelah dilakukan penerapan metode perbaikan dengan SMED.

\section{METODE PENELITIAN}

Penelitian ini merupakan penelitian eksperimental dengan implementasi melalui metode SMED, yaitu efisiensi waktu analisa kemasan primer flexy bag. pada parameter pengujian menggunakan data berupa hasil observasi yang didapatkan langsung dari pengamatan terhadap obyek yang diteliti dengan melakukan studi waktu, untuk waktu set-up analisa kemasan primer flexy bag. Sedangkan data sekunder didapatkan berdasarkan sumber-sumber yang terpercaya dengan membaca dan mempelajari literatur-literatur berbagai sumber referensi (buku, e-book dan jurnal).

Alat yang digunakan adalah stopwatch dan kalkulator. Sedangkan bahannya, yaitu flexy bag 50 $\mathrm{ml} \mathrm{pp}$ (Technoflex). Teknik sampling untuk penelitian ini menggunakan random sampling atau sampling acak dalam pengambilan sampel dari 1 nomor bets pada 32 vat dengan mengambil sampel di posisi atas, samping kanan dan samping kiri. Metode sampling kemasan dari sejumlah wadah menggunakan metode pola $n$. Berdasarkan BPOM (2012), pola $n=\sqrt{ } N+1$. Sampel dapat diambil dari bagian manapun dari wadah (umumnya dari lapisan atas). Jika jumlah wadah yang diambil dari 32 vat, maka jumlah wadah yang diambil contohnya adalah $\sqrt{32}+1=5,6+1$ $=6,6$ dibulatkan menjadi 7 wadah. Pengambilan sampel yang di tetapkan perusahaan pada kemasan primer flexy bag yaitu dengan jumlah contoh untuk pemeriksaan 15 pcs dari 7 wadah yang diambil sampelnya. Data yang telah didapatkan dari hasil pengumpulan data dilapangan dengan menghitung waktu pada setiap proses analisa dalam parameter pengujian yang dilakukan. Selanjutnya akan dilakukan pengolahan data menggunakan pendekatan dengan metode SMED, untuk mengetahui apa saja jenis parameter pengujian yang dapat dipararelkan. Tahapan umum dalam pengolahan data adalah sebagai berikut:
1. Perhitungan Waktu Normal 
Menghitung waktu setiap proses analisa dalam parameter pengujian yang dilakukan berdasarkan hasil dari pengumpulan data pada saat observasi langsung dilapangan. Pencatatan dan perhitungan waktu diawali dari persiapan form pemeriksaan, kemudian memeriksa kelengkapan form penerimaan bahan awal, setelah itu dilakukan sampling kemasan. Selanjutnya lakukan perhitungan waktu ketika persiapan analisa, proses analisa hingga selesai analisa, dan pengisian form hasil analisa. untuk mengetahui waktu normal dari pemeriksaan kemasan primer flexy bag yaitu, dengan menambahkan hasil perhitungan pada setiap parameter pengujian yang telah dilakukan.

2. Perhitungan Waktu dengan SMED

a. Langkah Pendahuluan

Mengetahui parameter pengujian yang dilakukan operator saat melakukan analisa tanpa membedakan parameter pengujian antara proses analisa internal dan eksternal.

b. Langkah Pertama

Memisahkan waktu internal set-up dan eksternal set-up. Internal set-up merupakan proses set-up pada saat analisa parameter pengujian yang tidak dapat dipararelkan, sedangkan eksternal set-up merupakan proses set-up yang dilakukan untuk parameter pengujian yang dapat dipararelkan.

c. Langkah kedua

Mengubah internal set-up menjadi eksternal set-up. Cara mengubah internal set-up menjadi eksternal set-up yaitu, dengan melakukan langkah pemeriksaan kembali pada setiap proses analisa untuk melihat apakah ada langkah yang salah sehingga diasumsikan sebagai internal set-up. Kemudian temukan cara untuk mengubah langkah tersebut menjadi eksternal set-up.

d. Langkah ketiga

Menghitung waktu internal set-up dan eksternal set-up serta bandingkan dengan waktu normal yang dibutuhkan pada setiap parameter pengujian. Lakukan perbaikan internal set-up secara berkelanjutan dengan tujuan untuk meminimalkan waktu set-up internal agar waktu analisa dapat dikurangi dengan perampingan semua jenis parameter pengujian.

Metode analisa data yang digunakan adalah analisa univariat yang bertujuan untuk menjelaskan atau mendeskripsikan karakteristik setiap variabel penelitian sehingga dapat memudahkan pembaca dalam memahami data hasil penelitian.

\section{HASIL DAN PEMBAHASAN}

Penerapan metode SMED pada pengurangan lead time analisa kemasan primer flexy bag ini merupakan suatu alat untuk meminimasi waktu set-up internal menjadi eksternal pada parameter pengujian yang dilakukan. Berikut ini tabel hasil penetapan metode SMED pada perhitungan waktu hasil analisa kemasan primer flexy bag. 
Jurnal Inkofar * Volume 1 No. 1 Juli 2020 * ISSN: 2615-3645 (Print) / 2581-2920 (Online)

Tersedia secara online di: http://www.politeknikmeta.ac.id/meta/ojs/

Tabel 1. Hasil perhitungan waktu dengan SMED

\begin{tabular}{|c|c|c|c|c|}
\hline \multirow{3}{*}{ Material } & \multirow{3}{*}{ Parameter } & \multicolumn{3}{|c|}{ Waktu (Menit) } \\
\hline & & \multirow{2}{*}{ Normal } & \multicolumn{2}{|c|}{ Metode SMED } \\
\hline & & & Internal & External \\
\hline \multirow{26}{*}{$\begin{array}{c}\text { Flexy } \\
\text { Bag } \\
32 \text { Vat }\end{array}$} & Persiapan form & 6 & 6 & \\
\hline & Pemeriksaan form awal & 5 & 5 & \\
\hline & Persiapan sampling & 60 & 60 & \\
\hline & Sampling & 20 & 20 & \\
\hline & Uji dimensi & 32 & 32 & \\
\hline & Persiapan uji hidrolitik & 5 & 5 & \\
\hline & Uji hidrolitik & 250 & & 250 \\
\hline & Persiapan uji kebocoran steril & 25 & 25 & \\
\hline & Uji kebocoran steril & 160 & & 160 \\
\hline & Uji spektrum UV & 6 & 6 & \\
\hline & Uji appearance & 4 & 4 & \\
\hline & Uji transparansi & 5 & 5 & \\
\hline & Persiapan uji sisa pemijaran & 44 & 44 & \\
\hline & Uji sisa pemijaran & 271 & & 271 \\
\hline & Persiapan uji sisa penguapan & 15 & 15 & \\
\hline & Uji sisa penguapan & 80 & & 80 \\
\hline & Uji senyawa tereduksi & 29 & 29 & \\
\hline & Uji buih & 8 & 8 & \\
\hline & Uji pH & 4 & 4 & \\
\hline & Uji batas logam berat & 270 & 270 & \\
\hline & Persiapan uji cairan penetran & 25 & 25 & \\
\hline & Uji cairan penetran & 30 & & 30 \\
\hline & Pengisian form hasil analisa & 8 & 8 & \\
\hline & Menit & 1.362 & 571 & 791 \\
\hline & Total lead time & 22,7 & 9,52 & 13,18 \\
\hline & Persentase & $100 \%$ & $41,94 \%$ & $58,06 \%$ \\
\hline
\end{tabular}

Data pada Tabel 1. Menunjukkan bahwa penerapan metode SMED pada satu nomor best dengan jumlah 32 vat untuk 23 parameter didapatkan hasil setelah melakukan 4 tahap dalam langkah penerapan sebagai berikut:

Lead time adalah waktu yang diperlukan untuk menyelesaikan serangkaian proses, terdiri dari waktu proses sebagai value added dan waktu pemborosan sebagai non value added termasuk didalamnya menunggu (waiting) dan hambatan (delays) (Martin, 2013 dalam Zahra, K.S.L.D. 2015). Pemborosan waktu dapat mengakibatkan keterlambatan dengan lead time yang panjang dan berpengaruh terhadap penyesuaian industri farmasi dalam kecepatan memenuhi kebutuhan konsumen. Perbaikan yang dapat digunakan dalam meminimalisir pemborosan waktu adalah dengan mereduksi waktu set-up menggunakan metode Single Minute Exchange of Dies (SMED).

Penerapan metode SMED mengacu pada teori dan teknik yang digunakan untuk pengurangan waktu set-up peralatan yang harus dilaksanakan dalam empat fase yang berbeda pada tahap A, di mana perusahaan tidak membuat perbedaan antara set-up operasi internal dan eksternal dan tahap B, di mana perusahaan memisahkan internal dari eksternal operasi set-up. Sedangkan tahap C, di mana perusahaan melakukan perubahan maksimum operasi set-up internal menjadi eksternal. Sehingga dapat dilakukan pada tahap D, untuk memperlancar semua aspek operasi set-up (Shingo, 1985). 
Penerapan metode SMED pada pengurangan lead time analisa kemasan primer flexy bag ini merupakan suatu alat untuk meminimasi waktu set-up internal menjadi eksternal pada parameter pengujian yang dilakukan. Metode ini dilakukan dengan 4 tahap pada tahap A, di lakukan langkah pendahuluan dengan cara pencatatan langsung terhadap aktivitas - aktivitas yang bersangkutan pada proses analisa kemasan primer flexy bag. Kemudian menghitung waktu yang dihabiskan selama proses tersebut berlangsung pada tahap ini didapatkan waktu normal proses analisa 22,7 jam dengan waktu kerja 8 jam, proses analisa dapat diselesaikan selama 3 hari.

Langkah selanjutnya setelah tahap pendahuluan adalah mengklasifikasikan aktivitas internal dan eksternal yang merupakan tahap B. Dilakukan untuk mengetahui aktifitas mana yang tidak memberikan nilai tambah. Sehingga dapat mengurangi waste, aktivitas internal adalah aktivitas yang tidak dapat dipararelkan dan aktivitas eksternal adalah aktivitas yang dapat dipararelkan. pada parameter pengujian ini terdapat 18 aktivitas internal dan 5 aktivitas eksternal.

Penggantian aktivitas internal menjadi aktivitas eksternal merupakan tahap C, dalam langkah ini dilakukan identifikasi aktivitas internal mana yang memungkinkan untuk dapat dikonversi menjadi aktivitas eksternal. Aktivitas eksternal lebih dapat diterima karena aktivitas ini dilakukan pada saat proses analisa berlangsung. Ketika sedang melakukan analisa menggunakan suatu alat, maupun metode tertentu yang menyebabkan analis menunggu proses tersebut, analis dapat melakukan analisa yang lain pada aktivitas internal. Sehingga dalam satu waktu dapat mengerjakan dua atau lebih pekerjaan lainnya secara bersamaan dan waktu analisa bisa lebih singkat.

Mengkonversi aktivitas internal menjadi aktivitas eksternal tidak ada acuan khusus. Maka untuk melakukan konversi didasarkan pada proses analisa. Ketika alat beroperasi saat proses analisa pada aktivitas eksternal, analis dalam keadaan menunggu. Keadaan menunggu ini juga merupakan wasting time. Karena mereka hanya menunggu sampai tahapan analisa pada alat, maupun proses analisa dengan metode tertentu yang harus menunggu sampai menunjukan suatu hasil dalam analisa. Untuk memanfaatkan waktu yang ada, sebaiknya analis melakukan kegiatan set-up pada parameter pengujian yang lainnya. Sehingga, analis tetap produktif.

Waktu set-up proses analisa berdasarkan perhitungan secara tidak langsung dengan memindahkan beberapa aktivitas internal menjadi eksternal, untuk mendapatkan lead time sebelum dan setelah mengkonversi aktivitas internal menjadi eksternal yang hasilnya dapat dilihat pada tabel 1. Lead time proses analisa kemasan primer flexy bag dengan menggunakan 1 nomor bats dari 32 vat pada aktivitas internal didapatkan hasil waktu pengisian form 6 menit, pemeriksaan form awal 5 menit, persiapan sampling 60 menit, sampling 20 menit, uji dimensi 32 menit, persiapan uji hidrolitik 5 menit, persiapan uji kebocoran steril 25 menit, uji spektrum UV 6 menit, uji appearance 4 menit, uji transparansi 5 menit, persiapan uji sisa pemijaran 44 menit, persiapan uji sisa penguapan 15 menit, uji senyawa tereduksi 29 menit, uji buih 8 menit, uji pH 4 menit, uji batas logam berat 270 menit, persiapan uji cairan penetran 25 menit dan pengisian form hasil analisa 8 menit. Sedangkan pada aktivitas eksternal didapatkan hasil dari parameter pengujian saat uji hidrolitik membutuhkan waktu 250 menit, uji kebocoran steril 160 menit, uji sisa pemijaran 271 menit, uji sisa penguapan 80 menit dan uji cairan penetran 30 menit.

Konversi aktivitas internal menjadi aktivitas eksternal pada proses analisa kemasan primer flexy bag di atas, untuk aktivitas eksternal set-up sebagian besar berupa aktivitas-aktivitas yang tidak mempunyai nilai tambah. Sebagai contoh, pada uji hidrolitik yang membutuhkan waktu 250 menit, pengujian ini menggunakan alat yang ada pada ruangan mikrobiologi dan dilakukan oleh analis mereka. Selama menunggu proses tersebut bisa dilakukan persiapan uji kebocoran steril. Selanjutnya akan dilakukan pengujian dengan waktu yang sudah dihitung selama 160 menit. Menggunakan alat yang ada pada departemen produksi dengan menunggu produk, karena dilakukan bersamaan saat sterilisasi produk oleh operator produksi. 
Aktivitas lain yang dapat dilakukan terlebih dahulu, yaitu uji sisa pemijaran yang membutuhkan waktu 271 menit dengan menggunakan alat tanur pada proses analisa, untuk peleburan dapat dilakukan bersamaan dengan uji batas logam berat yang membutuhkan waktu pemijaran \pm 3 jam. Selanjutnya lakukan terlebih dahulu persiapan uji cairan penetran dengan pengujian selama 30 menit, untuk memastikan ada tidaknya kebocoran pada flexy bag. Selama melakukan proses tersebut, uji hidrolitik sudah selesai dan dilanjutkan dengan pengujian lain yang membutuhkan cairan hasil dari hidrolitik. Lakukan terlebih dahulu uji sisa penguapan karena harus menggunakan oven dan pengujian ini membutuhkan waktu selama 80 menit, untuk selanjutnya dapat dilakukan pengujian seperti uji spektum UV, uji transparansi, uji buih, uji $\mathrm{pH}$ dan uji senyawa tereduksi. Aktivitas ini merupakan tahap D, dalam penerapan SMED dengan memberikan usulan perbaikan untuk menyelesaikan tugas-tugas yang berbeda dangan mudah, cepat dan cara yang aman.

Setelah penerapan SMED, selisih total perhitungan lead time analisa kemasan primer flexy bag sebelum dan setelah, untuk hasil dari pengamatan serta perhitungan terhadap 18 aktivitas internal dan 5 aktivitas eksternal adalah yang sebelumnya selama 22,7 jam menjadi 9,52 jam sehingga menghemat waktu kerja 13,18 jam dengan pengurangan waktu sebesar 58,06\%.

Berdasarkan penjelasan dari Shingo (1985), penerapan metode SMED terutama berfokus pada aktivitas kegiatan internal dan eksternal dengan transfer kegiatan internal menjadi aktivitas eksternal dalam jumlah sebanyak mungkin untuk meminimalkan aktivitas internal. Secara umum, SMED bertujuan untuk membakukan dan menyederhanakan operasi. Dengan penerapan metode ini aktivitas internal dapat diminimalkan. Sehingga dapat mengefisienkan waktu.

Dalam penelitian yang dihasilkan oleh Mulyana dan Hasibuan (2017), mengenai implementasi SMED untuk optimasi waktu changeover model pada produksi panel telekomunikasi dengan hasil penerapan konsep SMED yang dilakukan dengan mengubah 15 aktivitas internal menjadi 5 aktivitas internal dan merekayasa alat bantu gauge tool untuk mengurangi downtime mesin. Improvement yang diperoleh adalah berkurangnya waktu downtime mesin punching dari 44,90 jam menjadi 10,96 jam atau terjadi penurunan waktu set-up sebesar 75, 59 persen. Sedangkan penelitian lain yang dilakukan oleh Arief dan Ikatrinasari (2018), terkait perbaikan waktu set-up dengan menggunakan SMED pada mesin filling krim. Hasil penelitian tersebut menunjukkan bahwa metode SMED dapat dilakukan dengan memisahkan kegiatan set-up menjadi dua tahap yaitu internal set-up dan eksternal set-up sehingga proses set-up dan change over menjadi lebih efektif. Penerapan metode SMED pada penelitian ini menghasilkan penurunan waktu set-up sebanyak $26 \%$ atau 16 menit.

\section{KESIMPULAN}

Berdasarkan pembahasan pada implementasi metode SMED dalam pengurangan lead time analisa kemasan primer flexy bag. Menunjukan hasil yang dapat mengefisienkan waktu dengan meminimalkan aktivitas internal. Sehingga didapatkan penurunan waktu set-up sebasar 58,06\% atau 13,18 jam.

\section{DAFTAR PUSTAKA}

Anonim. 2001. The Japanese Pharmacopoeia. 14 ${ }^{\text {th }}$ Edition. Tokyo: The Ministry of Health. Labour and Welfare. Hal 43, 95-97 dan 1319.

Arief, N. \& Ikatrinasari, F. 2018. Perbaikan Waktu Set-up dengan Menggunakan Metode SMED pada Mesin Filling Krim. Jurnal Ilmiah Teknik Industri, Vol. 6 No. 1, $1-8$.

BPOM. 2012. Penerapan Pedoman Cara Pembuatan Obat yang Baik. Jakarta: Badan Pengawas Obat dan Makanan Republik Indonesia.

BPOM. 2018. Penerapan Pedoman Cara Pembuatan Obat yang Baik. Jakarta: Badan Pengawas Obat dan Makanan Republik Indonesia. 
Guidelines on Packaging for Pharmaceutical Product World Health Organization. 2002. Technical Report Series 902. Geneva: WHO.

Julianti, S. 2018. The Art of Packaging. Jakarta: Gramedia Pustaka Utama.

Mulyana, A., \& Hasibuan, S. 2017. Implementasi Single Minute Exchane of Dies (SMED) untuk Optimasi Waktu Changeover Model Produksi pada Panel Telekomunikasi. SINERGI 21, 107-114. Niebel.

Shingo, S. 1985. A Revolution in Manufacturing: The SMED System. Cambridge: Productivity Press.

Sivakumar, M., Balasubramani, T., \& Stany, M. C. 2015. Lean Manufacturing in Carriage Building Press Shop Using by SMED and VSM Tools. International Journal of Innovations in Engineering and Technology (IJIET). 5(3), 235-241.

Zahra, K.S.L.D. 2015. Penggunaan Konsep Lean untuk Meningkatkan Efisiensi Pelayanan Instalasi Farmasi Rawat Jalan di Rumah Sakit Anna Medika Bekasi. Jurnal Administrasi Rumah Sakit, Vol. 2 No. 1. 